\title{
REHABILITAS PASCA COVID-19 DARI SEGI FISIK
}

\author{
Khaerul Anam ${ }^{1}$, Lilik Evitamala ${ }^{2}$, Hariadi $^{3}$ \\ Email : $\underline{\text { khaerulanam@ @ununtb.ac.id }}{ }^{1}$, lilikevitmala23@ gmail.com ${ }^{2}$, hariadi@ hamzanwadi.ac.id ${ }^{2}$ \\ ${ }^{\mathbf{1 , 2}}$ Universitas Nahdatul Ulama Nusa Tenggara Barat, ${ }^{\mathbf{3}}$ Universitas Hamzanwadi
}

\begin{abstract}
Abstrak
Berdasarkan Ovservasi yang dilkukan peneliti sebagai pelatih kebugaran pada klien pasca Covid-19 pada member @ personal trainer Lombok, aktivitas latihan masih rendah terlihat dari frekunesi, intensitas durasi dan tipe latihan yang dilkukan. klien penyintas Covid banyak yang masih mengeluhkan kondisi fisik mereka, maka penting untuk memberikan rehabilitas dari segi fisik Metode penelitian yang digunakan adalah metode penelitian diskriptif studi kasus yang berjumlah satu variable tampa membuat komparasi, atauw mengkorelasikan dengan variable yang lain.Tujuan dari penelitian ini adalah memberikan Kebugaran pada klien/member personal trainer yang diakumulasi dengan pemberian beban latihan dengan Frekuensi, Intensitas, Time dan Tipe latihann serta waktu istirahat, latihan pernafasan diapragma serta meberikan intervensi terhadap beban latihan yang harus dilakukan. Hasil kegiatan ini menunjukan intervensi latihan fisik menunjukkan hasil yang signifikan
\end{abstract}

Kata Kunci: Rehabilitas Pasca covid-19; segifisik.

\begin{abstract}
Based on observations carried out by researchers as fitness trainers for post-Covid-19 clients on members of Lombok's personal trainer, exercise activity is still low, seen from the frequency, intensity, duration and type of exercise performed. clients still complain about their physical condition, so it is important to provide physical rehabilitation. The research method used is a case study descriptive research method which consists of one variable without making comparisons. correlated with other variables. The purpose of this study is to provide fitness to the client personal trainer which is accumulated by providing training loads with frequency, intensity, Time and type of exercise as well as rest periods, diaphragmatic breathing exercises and provide intervention on the training load that must be done. The results of this activity show that the physical exercise intervention shows significant results.
\end{abstract}

Keywords: Post-Covid-19 Rehabilitation; Physical Aspect.

\section{A. Pendahuluan}

Perawatan pasca covid bertujuan untuk meningkatan sitema komponen anatomi tubuh kembali seperti semula serta mengurangi kecacatan jangka panjang dan memungkinkan pasien hidup kembali ke masyarakat. Program rehailitas pasca covid-19 mempunya program yang berbeda pada setiap klien baik pada fungsi nafas atau pernafasan, fungsi motorik termasuk kekuatan dan dayatahan otot, fleksiilitas, gerakan aktif sendi dan termasuk aspek psikologis yang terkait dengan kondisi pada saat dinyatakan positif. Fase perawatan pasca akut dianggap lebih tepat untuk memuliai rehabilitas karna sebagian besar pasien tampak stabil secara medis, penguatan latihan keseimbangan dan kordinasi menggunakan treatmil ringan maupun jalan santai di taman dengan ditemani coach disamping akan membuat klien 
merasa diperhatian dan hal ini akan berdampak terhadap emosional dan psikologis klien, terapi pernafasan juga diperlukan untuk meningkatakn Vo2Max klien. Vo2Max adalah tingkat maksimum oksigen yang dapat digunakan tubuh selama berolahraga diukur dengan satuan Mililiter(ML) Oksigen yang dikonsumsi dalam satu menit per kilogram berat badan anda (ml/kg/menit) Oksigen adalah bagian paling penting dalam pernafasan Vo2Max yang baik untuk laki-laki berusia 25 tahun adalah 42,5 sampai dengan 46,4 Ml./Kg/Menit. Dan untuk wanita adalah usia 25 tahun adalah 33,0 sampai dengan 36,9 Ml/Kg7Menit. Cara untuk memberikan kenaikan V02Max adalah dengan cara latihan di treaatmil maupun lari dan sprint secara bertahap dan hal ini akan membuat klien pasca covid akan lebih cepat dalam meningkatakan kinerja organnya untuk menjadi lebih baik.

Nyeri pada penyintas Covid-19 hal yang saya rasakan sewaktu di rawat di jogja adalah emosional yang tidak menyenangkan kemampuan fisik sangat menurun yang disebabkan deman tingga, kondisi tubuh yang tidak stabil. Sama hal nya dengan kegiatan yang saya ikuti khawatir saya juga merasakan hal tersebut. Pemeriksaan kondisi fisik dimulai dari unum, dari cara berjalan postur, kondisi mental, nutrisi dan cara berpakaian ini sama dengan pemeriksaan kondisi kebugaran jasmani seperti awal. Kemampuan otot perut, kemampuan otot kaki, dan otot lengan, Seiring dengan tingginya tingkat infektivitas dan tingkat kematian, Corona Virus Disease 2019 (COVID-19) telah menimbulkan dampak psikososial universal dengan menimbulkan histeria massal, beban ekonomi dan kerugian finansial. Ketakutan massal terhadap COVID-19, yang disebut sebagai "coronaphobia", telah menghasilkan sejumlah besar manifestasi kejiwaan di berbagai lapisan masyarakat. Jadi, tinjauan ini dilakukan untuk menentukan dampak psikososial COVID-19. Metode: Pubmed dan GoogleScholar dicari dengan istilah kunci berikut- "COVID-19", "SARS-CoV2", "Pandemic", "Psikologi", "Psikososial", "Psikiatri", "terpinggirkan", "telemedis", “ kesehatan mental", "karantina", "infodemik", "media sosial" dan "internet". Beberapa laporan surat kabar terkait dengan COVID-19 dan dampak psikososial juga telah ditambahkan sesuai konteks. Program mitigasi berbasis masyarakat untuk memerangi COVID-19 akan mengganggu gaya hidup biasa anak-anak dan dapat menyebabkan tekanan mental yang buruk. Aspek psikososial lansia, pengasuhnya, pasien gangguan jiwa, dan komunitas terpinggirkan dipengaruhi oleh pandemi ini dengan cara yang berbeda dan memerlukan perhatian khusus. Untuk mengatasi masalah psikososial dari berbagai lapisan masyarakat dengan lebih baik, model pencegahan dan intervensi krisis psikososial harus segera dikembangkan oleh pemerintah, petugas kesehatan dan pemangku kepentingan lainnya. Penerapan layanan internet, teknologi, dan media sosial yang tepat untuk meredam pandemi dan infodemik perlu digalakkan. Kesiapsiagaan psikososial dengan mendirikan organisasi mental khusus untuk pandemi di masa depan tentu diperlukan.(Dubey et al., 2020) Rehabilitas merupakan komponen kunci pemulihan penyakit dan intervensi dengan kondisi fisik

\section{B. Metode}

Metode penelitian yang digunakan peneliti adalah memberikan intervensi dari segi fisik pada klien atau member club personal trainer Lombok yang berjumalah 17 orang dengan masing-masing usia dan kebutuhan yang berbeda-beda karna tingkat perbedaan klien yang dimiliki sehingga perlakukan yang diberikan akan cenderung berbeda beda hal ini berdasarkan table di bawah ini. 
Creating Productive and Upcoming Sport Education Profesional Hmzanwadi University

Vol.4, No.2, Desember 2021, Hal. 76-80

e-ISSN 2614-8781

\begin{tabular}{|c|c|c|c|c|c|}
\hline Statistik & Perlakuan & Intensitas & $\begin{array}{l}\text { Saturasi } \\
\text { oksigen }\end{array}$ & DN Rest & $\begin{array}{l}\text { Tekanan } \\
\text { darah }\end{array}$ \\
\hline $\begin{array}{l}\text { Usia } \\
\text { produktif } \\
14 \text { orang }\end{array}$ & $\begin{array}{l}\text { Penguatan otot } \\
\text { dan } \\
\text { cardiovaskuler }\end{array}$ & $\begin{array}{l}\text { 3x dalam } \\
\text { seminggu } \\
\text { Ringan - } \\
\text { sedang -tinggi } \\
70 \%\end{array}$ & 90/Normal & $\begin{array}{l}\text { Rata-rata } \\
80\end{array}$ & $120 / 80$ \\
\hline $\begin{array}{l}\text { Uisa } \\
\text { lanjut } 3 \\
\text { orang }\end{array}$ & $\begin{array}{l}\text { Penguatan otot } \\
\text { dan } \\
\text { cardiovaskuler }\end{array}$ & $\begin{array}{l}3 x \text { dalam } \\
\text { seminggu } \\
\text { Ringan } 40 \%\end{array}$ & 90/Normal & $80 / 90$ & $140 / 90$ \\
\hline
\end{tabular}

Berdasarkan usia produktif 14 orang diberikan latihan intervensi sebanyak tiga kali dalam seminggu dan diberikan latihan penguatan otot serta latihan cardio renang dan jogging ringan di atas treatmil dengan selalu mengecek saturasi oksigen dan detak nadi sehingga kita benar-benar memonitoring hasil dan kegiatan pembebanan latihan yang diberikan terhadap klien personal trainer Lombok alat yang digunakan seperti oximeter, jam digital sehingga kita bisa menghitung lankah dan memonitoring kinerja paru jantung. Sama hal ya juga pemberian beban terhadap klien lanjut usia diberikan secara perlahan dan berkelanjutan sehingga kebugaran jasmani cepat kembali pulih. Olahraga yang secara spesifik dapat meningkatkan derajat kesehatan bagi pelakunya. Dalam olahraga kesehatan tidak hanya melatih aspek jasmaniah, juga menjangkau aspek rohaniah dan aspek sosial. Kesadaran masyarakat untuk berolahraga memberikan kontribusi dalam pembangunan individu dan masyarakat yang cerdas, sehat, terampil, tangguh, kompetitif, sejahtera, dan bermartabat.

\section{Hasil dan Pembahasan}

Olahraga pada dasarnya merupakan kebutuhan setiap manusia di dalam kehidupan, agar kondisi fisik dan kesehatannya tetap terjaga dengan baik. Olahraga dapat meningkatkan kesehatan dan mencegah timbulnya penyakit termasuk penyakit jantung, diabetes tipe 2, osteoporosis, bentuk kanker, obesitas, dan cedera. Partisipasi dalam olahraga juga dikenal untuk mengurangi depresi, stres dan kecemasan, meningkatkan kepercayaan diri, tingkat energi, kualitas tidur, dan kemampuan untuk berkonsentrasi. Ada tiga faktor yang berdampak pada partisipasi olahraga, yaitu faktor individu, faktor lingkungan, dan faktor sosial budaya. Partisipasi masyarakat dalam melakukan kegiatan olahraga semakin meningkat yang ditunjukkan dengan peningkatan partisipasi masyarakat pada indeks pembangunan olahraga (SDI). (Prasetyo, 2015) Rehabilitasi pasca Covid-19 dilakukan secara bertahap, terencana, terukur dan teratur

Latihan fisik sangat bermanfaat bagi individu yang sehat maupun yang memiliki resiko untuk terjadinya Penyakit Kardio Vaskular (PKV). Latihan fisik teratur menurunkan risiko PKV dengan cara: mengurangi trigliserida, meningkatkan kolesterol HDL, menurunkan tekanan darah, meningkatkan metabolisme glukosa serta sensitivitas insulin, mengurangi berat badan dan mengurangi respon inflamasi. Hipertrofi jantung fisologis memberikan efek kardioprotektif dan tidak terkait dengan gagal jantung. Sedangkan hipertrofi patologis dikaitkan dengan keparahan penyakit kardiovaskular yang menyebabkan peningkatan risiko gagal jantung, aritmia dan berakhir kematian. (Hamdani \& Hasye, 2019) Pengaruh Latihan Fisik Terhadap Vo2 max Mahasiswa Tingkat 1 Jurusan Fisioterapi Poltekkes Makassar. Penelitian ini termasuk penelitian eksperimen lapangan yang melibatkan variabel perlakuan yaitu latihan fisik, sedangkan variabel respons adalah Vo2 max. Desain 
penelitian adalah Quasy experiment dengan desain pretest-post test two group design. Populasi penelitian adalah mahasiswa tingkat 1 program studi D.III Fisioterapi Poltekkes Kemenkes Makassar sebanyak 50 orang, sedangkan sampel mahasiswa tingkat 1 program studi (Tang \& Thahir, 2020). Rehabilias pasca covid dapat memberikan pemulihan secara signifikan terhadap kemampuan tubuh sehingga penyakit hipertensi bisa di cegah sedini mungkin. Hipertensi merupakan faktor risiko utama penyakit kardiovaskular yang dapat meningkatkan morbiditas dan mortalitas. Latihan fisik merupakan salah satu bentuk upaya nonfarmakologis pencegahan, pengobatan serta rehabilitasi pasien hipertensi. Dosis latihan fisik hendaknya sesuai kondisi masing-masing penderita hipertensi. (Sarastuti \& Widyantoro, 2018)

\section{Simpulan}

Kesimpulan dari penelitian ini menunjukkan bahwa intervensi rehap klien pada member personal trainer lombok dari segi fisik dapat memberikan hasil yang sangat baik dari peningkatan kemampuan core stabiliti, daya tahan otot dan kemampuan jantung paru dalam memompa darah keseluruh tubuh sebagai penyitas Covid-19 hal ini peneliti rasakan dan peneliti kembangkan terhadap kemampuan tubuh kembali seperti sedia kala dan dapat beraktivitas dalam lingkungan masyarakat sertadapat mensyukuri nikmat alloh SWT.

\section{Daftar Pustaka}

Agustia, D. (2021). Apakah Screen Time Menurunkan Tingkat Aktivitas Fisik Siswa Selama Pandemi COVID-19?. Jurnal Psikologi dan Pendidikan , 58 (2), 6033-6040.

Dubey, S., Biswas, P., Ghosh, R., Chatterjee, S., Dubey, M. J., Chatterjee, S., ... Lavie, C. J. (2020). Psychosocial impact of COVID-19. Diabetes and Metabolic Syndrome:

Clinical Research and Reviews. https://doi.org/10.1016/j.dsx.2020.05.035

Hamdani, R., \& Hasye, F. A. (2019). Efek Latihan Fisik Terhadap Remodeling Jantung. Jurnal Kesehatan Andalas, 8(2), 427. https://doi.org/10.25077/jka.v8.i2.p427437.2019

Hidayat, A. K., Nugroho, A. I., Dongoran, M. F., Lahinda, J., \& Syamsudin, S. (2021). Profil Kondisi Fisik Atlet Bulutangkis Junior IBIK Club Merauke Pasca Pemberlakuan New Normal Pandemi Covid-19. Musamus Journal of Physical Education and Sport (MJPES), 3(02), 204-217.

Harvianto, Y. (2021). Pengaruh Media Pembelajaran Interaktif Terhadap Hasil Belajar Pendidikan Jasmani Selama Masa Pandemi Covid-19. Jurnal Porkes , 4 (1), 1-7.

HUdah, M., Widiyatmoko, FA, Pradipta, GD, \& Maliki, O. (2020). Analisis Pembelajaran Pendidikan Jasmani Di Masa Pandemi Covid-19 Di Tinjau Dari Penggunaan Media Aplikasi Pembelajaran Dan Usia Guru. Jurnal Porkes , 3 (2), 93-102.

Kusuma, Y. L. H., \& Nada, S. (2021). Asuhan Keperawatan Keluarga Dengan Anggota Keluarga Mengalami Gangguan Mobilitas Fisik Pasca Stroke Di Masa Pandemi Covid-19 Di Desa Sooko Kec. Sooko Kab. Mojokerto. Medica Majapahit (JURNAL ILMIAH KESEHATAN SEKOLAH TINGGI ILMU KESEHATAN MAJAPAHIT), 13(1), 41-52.

Muhammad, H. N., Wahono, B. S., Listiandi, A. D., \& Budi, D. R. (2020). Bunga Rampai Strategi, Proses, Evaluasi, dan Model Pembelajaran Pendidikan Jasmani, Olahraga, dan Kesehatan (PJOK) pada Era Pandemi Covid-19. Unesa University Press.

Prasetyo, Y. (2015). Kesadaran Masyarakat Berolahraga Untuk Peningkatan Kesehatan Dan

Pembangunan Nasional. Medikora. https://doi.org/10.21831/medikora.v11i2.2819

Pambudi, A. S. (2021). KENDALA ADAPTASI PEMERINTAH DAERAH DALAM 
IMPLEMENTASI DAK FISIK SAAT PANDEMI COVID-19. Jurnal Ilmiah Wahana Bhakti Praja, 11(1), 1-17.

Sarastuti, A. W., \& Widyantoro, B. (2018). Latihan Fisik bagi Penderita Hipertensi. Jurnal Cermin Dunia Kedokteran (CDK).

Subardhini, M. Rehabilitasi Sosial bagi Penyandang Disabilitas sebagai Proses Perubahan Sosial Pasca Pandemi Covid-19.

Simanjuntak, EY, Octavia, YT, \& Romayanti, Y. (2021). Gambaran resiko penularan covid19 menggunakan self assessment inarisk pada mahasiswa perguruan. Jurnal Gawat Darurat , 3 (1), 53-62.

Suliswati, D., \& Razi, F. (2020). Kebijakan Pemerintah Desa Lowayu Kecamatan Dukun Kabupaten Gresik Dalam Rekonstruksi Ekonomi Pasca Pandemi Covid-19. Prosiding Penelitian dan Pengabdian kepada Masyarakat, 7(2), 348-359.

Saputro, AA, Saputra, YD, \& Prasetyo, GB (2020). Analisis Dampak Covid-19 Terhadap Kesadaran Masyarakat Dalam Penerapan Protokol Kesehatan. Jurnal Porkes , 3 (2), 81-92.

Saputro, AA (2021). Korelasi Latihan Mandiri Selama Pandemi Covid 19 Dengan Kecemasan Dan Depresi Atlit. Jurnal Porkes , 4 (1), 45-49.

Tang, A., \& Thahir, M. (2020). Efek Latihan Fisik Terhadap Vo2 Max Pada Mahasiswa. Media Kesehatan Politeknik Kesehatan Makassar. https://doi.org/10.32382/medkes.v15i2.1594

TRESNASARI, C., \& DHARMMIKA, S. (2020). COVID-19 dan tatalaksana kedokteran fisik serta rehabilitasi pasien. Pusat Penerbitan Unisba (P2U) LPPM UNISBA.

Wijayanto, A., \& Khurniawan, A. W. (2021). BUNGA RAMPAI Strategi Pembelajaran Pendidikan Jasmani Olahraga Dan Kesehatan Selama Pandemi Covid-19. 